University for Business and Technology in Kosovo

UBT Knowledge Center

UBT International Conference

2014 UBT International Conference

Nov 8th, 9:15 AM - 9:30 AM

\title{
The general energy audit in a primary school in Pristina - a case study
}

Mehmet Qelaj

Ministry of Economic Development, Pristina, Kosovo

Justina Shiroka-Pula

University of Prishtina

Andonaq Londo

University of Prishtina

Flamur Bidaj

University of Prishtina

Violeta Nushi

University of Prishtina

Follow this and additional works at: https://knowledgecenter.ubt-uni.net/conference

Part of the Architecture Commons

\section{Recommended Citation}

Qelaj, Mehmet; Shiroka-Pula, Justina; Londo, Andonaq; Bidaj, Flamur; and Nushi, Violeta, "The general energy audit in a primary school in Pristina - a case study" (2014). UBT International Conference. 1. https://knowledgecenter.ubt-uni.net/conference/2014/all-events/1

This Event is brought to you for free and open access by the Publication and Journals at UBT Knowledge Center. It has been accepted for inclusion in UBT International Conference by an authorized administrator of UBT Knowledge Center. For more information, please contact knowledge.center@ubt-uni.net. 


\title{
The general energy audit in a primary school in Pristina - a case study
}

\author{
Mehmet Qelaj ${ }^{1}$, Justina Shiroka-Pula ${ }^{2}$, Andonaq Londo ${ }^{3}$, Flamur Bidaj ${ }^{4}$, Violeta Nushi ${ }^{5}$ \\ ${ }^{1}$ Ministry of Economic Development Pristina, Kosovo \\ ${ }^{2}$ Faculty of Economics - UP Hasan Prishtina. Pristina, Kosovo \\ ${ }^{34}$ Faculty of Mechanical Engineering - UPT, Tirana, Albania \\ ${ }^{5}$ Faculty of Construction and Architecture - UP Hasan Prishtina. Pristina, Kosovo
}

\begin{abstract}
Energy Audit Standard of this educational object, presents the current existing situation of energy consumption, which enables us to identify energy consumption needs of small costs to those with high energy saving. The main goal is to achieve energy savings, energy saving measures (ESM), identify energy saving measures, the preparation of the document on energy saving measures, the implementation of these measures after finding them, etc. For the realization of standard energy audit facility records needed for billing of energy (electricity, fuels) for the last three years (or/and the following year); studies for building object as plans related structure construction and materialization mantle, energy installations and operations of the apparatus/basic equipment, including coolingheating, etc. Based on the methodology of the ASE, is explored in this paper about energy efficiency for the case study: Primary School in Pristina - Kosovo, to give appropriate recommendations towards high energy performance on particular educational facility and/or building facilities in general.
\end{abstract}

Keywords: audit standard, efficiency, consumption, saving, move.

\section{Introduction}

An energy audit is a general term for a systematic procedure that aims to gain adequate knowledge regarding energy consumption profile of a building or an industrial plant. It also aims to identify and balance the opportunities for saving energy cost-effective for the unit. Energy audits are important for the implementation of energy saving measures and targets for providing Energy Management. In an energy audit required to be conditions are met: a) energy saving, b) energy consumption and savings opportunities, c) other technical and environmental indicators of other aspects to be considered (the technical, environmental) are major energy savings, d) report on austerity measures energy, and d) the audit work can cover all aspects of energy use of a object or certain parts (equipment, systems) or several objects.

\subsection{Description of the existing situation of the object}

Cover object: Cover or exterior walls have openings - windows. As shown in Figure 1.a, most of the surface of the mantle is composed of windows.

The walls are built with clay bricks, Giter type with holes and continue plastered with loops on both sides, from outside and inside. The windows and doors were replaced in 2006. Plastic windows are double glazed with vacuum $2[\mathrm{~cm}]$ by manufacturer "LESNA". Profile of the window is $d=7[\mathrm{~cm}]$ Windows as well as doors are in very good condition and usable. Entresol structure (floor and ceiling): The floor was renovated in 2006. Through the office is laid laminate and ceramic tiles in corridors, figure $1[1]$. 


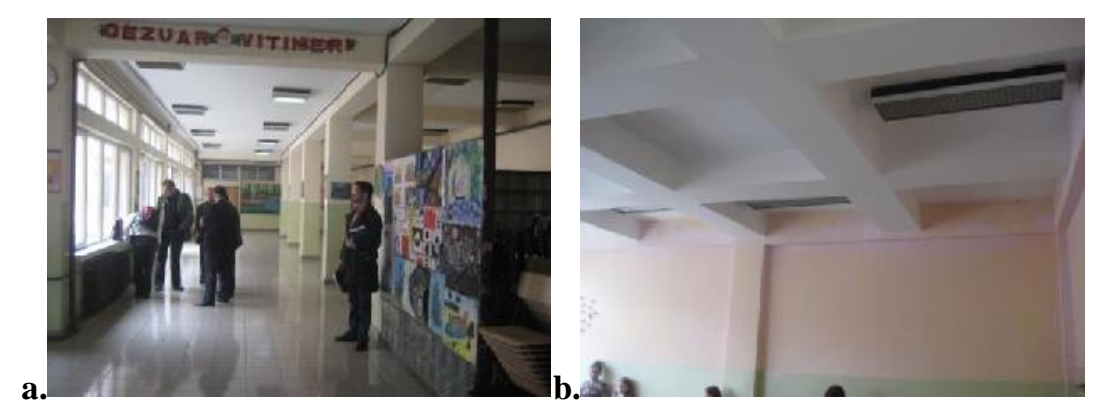

Fig. 1 View of the interior of the school building: a. mainly with windows wrapping and b. mid-floor roof from reinforced concrete

The roof: Because of damage to the flat roof waterproofing is doing a renovation in 2007 where the roof slope is determined by the construction of wood and covered with corrugated sheet.

\subsubsection{Calculation of important parameters}

Calculations of the most important architectural data for „Dardania”' Primary School in Pristina, (2010), are summarized and presented as follows (Table 1).

\begin{tabular}{|c|c|c|c|c|c|c|c|c|}
\hline \multicolumn{9}{|c|}{ Important parameters in the Primary School "Dardania" Pristina - November 2010} \\
\hline $\begin{array}{c}\text { Dwelling } \\
P+2\end{array}$ & $\begin{array}{l}\text { The } \\
\text { surface of } \\
\text { exterior } \\
\text { walls with } \\
\text { openings } \\
{\left[\mathrm{m}^{2}\right]}\end{array}$ & $\begin{array}{l}\text { Extenior } \\
\text { wall } \\
\text { surfaces } \\
\text { without } \\
\text { opening } \\
{\left[\mathrm{m}^{2}\right]}\end{array}$ & $\begin{array}{l}\text { The } \\
\text { surface of } \\
\text { exterior } \\
\text { windows } \\
\text { and doors } \\
{\left[\mathrm{m}^{2}\right]}\end{array}$ & $\begin{array}{l}\begin{array}{l}\text { Coridor } \\
\text { area }\end{array} \\
\text { uninsulated } \\
{\left[\mathrm{m}^{2}\right]}\end{array}$ & $\begin{array}{l}\text { Totalnet } \\
\text { area of } \\
\text { bases } \\
{\left[\mathrm{m}^{2}\right]}\end{array}$ & $\begin{array}{l}\text { Totalnet area } \\
\text { of physical } \\
\text { education hall } \\
\text { with } \\
\text { accompanying } \\
\text { space }\end{array}$ & $\begin{array}{l}\text { Volume } \\
\text { space } \\
{\left[\mathrm{m}^{3}\right]}\end{array}$ & $\begin{array}{l}\text { The } \\
\text { perimeter } \\
{[\mathrm{m}]}\end{array}$ \\
\hline $\begin{array}{l}\text { Ground } \\
\text { Floor }\end{array}$ & 13613.3 & 13268.7 & 344.56 & 727.55 & 2834.76 & 1300.45 & 9921.66 & 3714.41 \\
\hline Floor 1 & 2298.3 & 1962.9 & 335.14 & 572.21 & 1115.73 & & 3905.055 & 627.10 \\
\hline Floor 2 & 1320.8 & 1083.92 & 236.88 & 330.41 & 433.47 & & 1517.145 & 360.37 \\
\hline Total & 17232.4 & 5315.5 & 606.58 & 1630.17 & 4383.96 & 1300.45 & 15343.86 & 4701.98 \\
\hline \multicolumn{5}{|c|}{ Table of introducing spots heights $(\mathrm{H})$} & & & & \\
\hline \multicolumn{2}{|c|}{ Ground Floor } & \multicolumn{3}{|c|}{$320+30+10+6.5=366.5$} & & & & \\
\hline \multicolumn{2}{|l|}{ Floor 1} & \multicolumn{3}{|c|}{$320+30+10+6.5=366.5$} & & & & \\
\hline \multicolumn{2}{|l|}{ Floor 2} & \multicolumn{3}{|c|}{$320+30+10+6.5=366.5$} & & & & \\
\hline
\end{tabular}

\subsection{Electrical system}

In the corridors, in the classrooms, administrative spaces and other working spaces are located FC $2 \times 36$ $[W]$ fluorescent lamps and $4 x 18[W]$, while the bathrooms and carpeted spaces are located $1 \times 100$ $[W]$ incandescent lamps. 


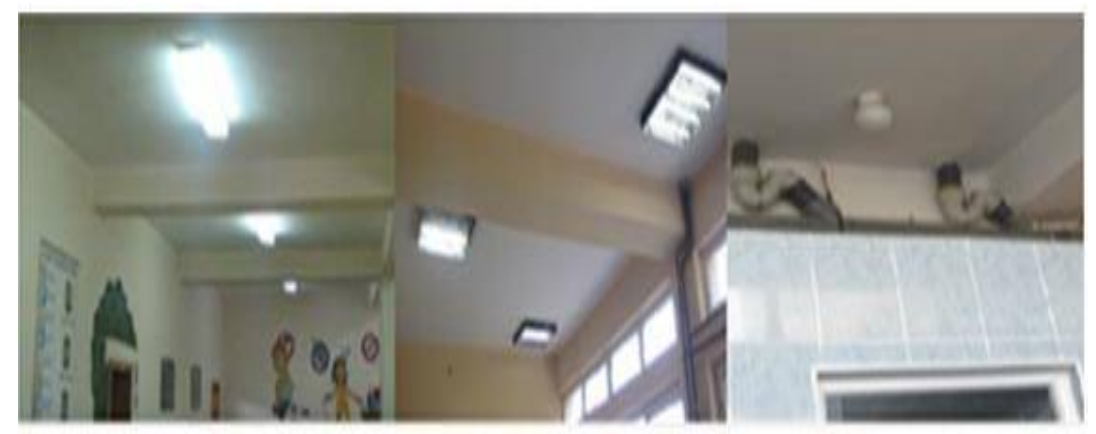

\begin{tabular}{|l|c|c|c|c|c|}
\hline \multicolumn{1}{|c|}{ Type } & No. & $\begin{array}{c}\text { Power } \\
{[\mathbf{k W ]}]}\end{array}$ & $\begin{array}{c}\text { The total } \\
\text { capacity } \\
\text { installed [kW] }\end{array}$ & $\begin{array}{c}\text { Yearly } \\
\text { hours of } \\
\text { operation }\end{array}$ & $\begin{array}{c}\text { Yearly energy } \\
\text { consumption } \\
{[\mathbf{k W h}]}\end{array}$ \\
\hline Fluorescent lighting T8/36 & 854 & 0.036 & 30.74 & 1000 & 30.744 \\
\hline Fluorescent lighting & 9 & 0.060 & 0.54 & 1000 & 540 \\
\hline Fluorescent lighting & 36 & 0.016 & 0.58 & 1000 & 576 \\
\hline Incoming reflector (fluorescent) & 1 & 0.200 & 0.20 & 1075 & 215 \\
\hline Gyms & 14 & 0.125 & 4.75 & 430 & 753 \\
\hline Lighting (incandescent) & 56 & 0.100 & 5.60 & 1000 & 5600 \\
\hline Pump boilers & 2 & 1.600 & 3.20 & 1000 & 3200 \\
\hline Electric boiler 80 [liters] & 1 & 2.000 & 2.00 & 1000 & 2000 \\
\hline Computers and TV & 5 & 0.200 & 1.00 & 1600 & 1600 \\
\hline Electric heat & 2 & 2.000 & 4.00 & 1000 & 4000 \\
\hline TOTAL & & & 49.61 & & 49228 \\
\hline
\end{tabular}

Fig. 2 Interior view of school lighting

Based on Table 1 and 2 and in Figure 3 shows that the total consumption for lighting and consumed just based on that fact as a measure to be taken to economize energy consumption in lighting, should be replacement of incandescent bulbs with lamps compact fluorescent. Table 2 Participation in total consumption:

\begin{tabular}{|l|c|c|}
\hline \multicolumn{1}{|c|}{ Type } & Energy consumed [kWh] & Participation in total consumption [\%] \\
\hline Lighting & 38428 & $78 \%$ \\
\hline Pump boilers & 3200 & $7 \%$ \\
\hline Electric boiler80 [liters] & 2000 & $4 \%$ \\
\hline Computers and TV & 1600 & $3 \%$ \\
\hline Electricheat & 4000 & $8 \%$ \\
\hline TOTALI & 49228 & $100 \%$ \\
\hline \multicolumn{3}{|c|}{ Participation in total } \\
\hline
\end{tabular}

Fig. 3 Participation in the total consumption in \%

Always based on the existing situation, the demand for electricity for lighting is 38428 [kWh/years]. Besides lighting, the school also has the following equipment: pumps boilers, electric boiler, computer, $\mathrm{TV}$ and electric heating. Based on the existing situation, the consumption of electricity for electric is approximately 10800 [kWh/year]. If consumption compared in Table 1 with consumption billed by KEK, resulting in a difference in consumption. Change in consumption is justified by the fact that during the year may be considered to electric lamps were not functioning, while the other factor are also power 
cuts during the year, of which vary from year to year. Should be taken into consideration during electricity reductions, electricity consumption is covered by electric generator but do not know the average annual time reductions.

\subsubsection{Energy Building}

Table 3 shows electricity consumption by month for the past three years. If consumption seen in July and August, shows that different from other months. Because in these months is yearly holiday.

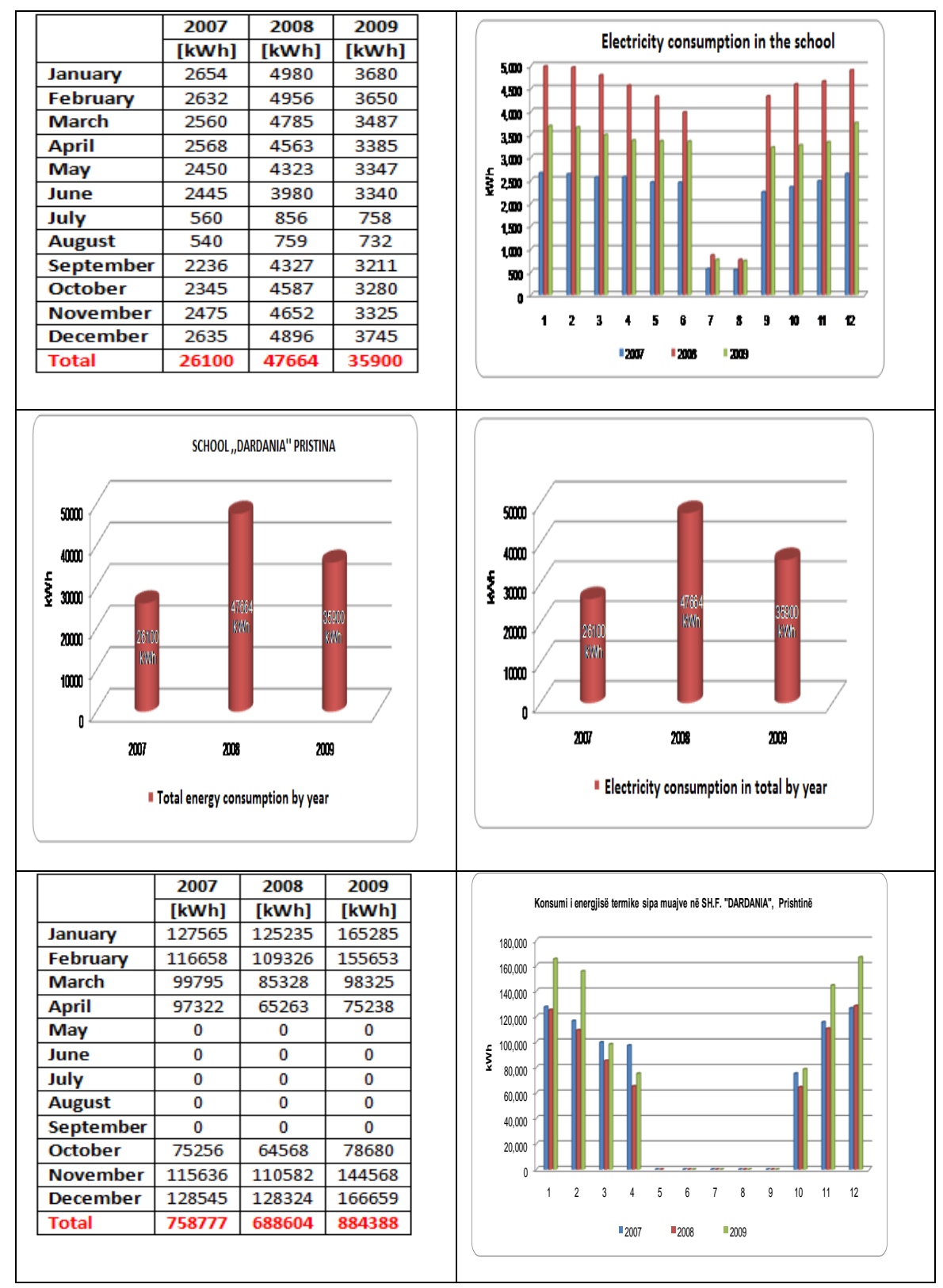




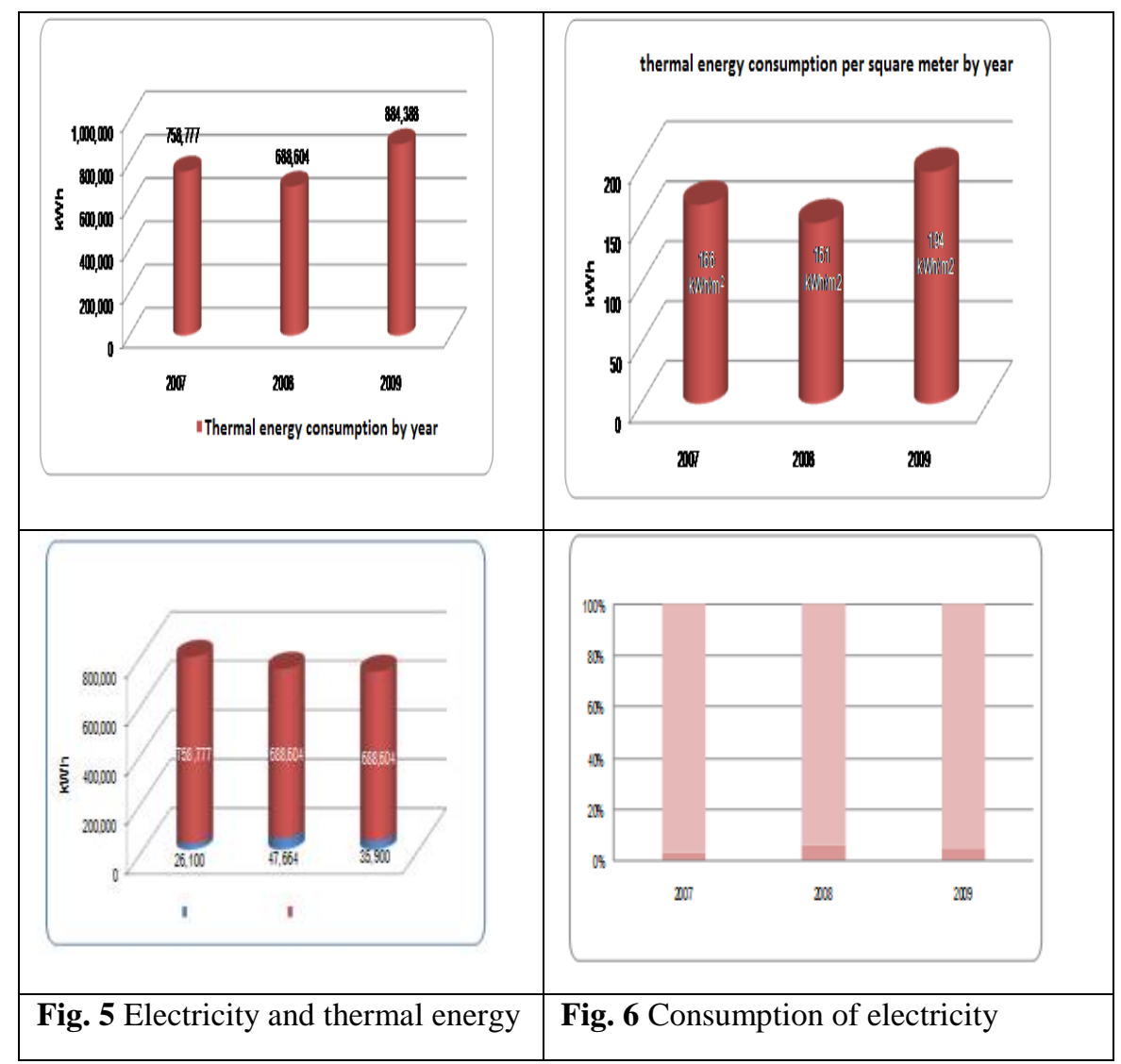

The figure indicates that consumption in 2008 was about 83 [\%] higher than consumption in 2007 to the fact that the learning process was held in 2008 with three shifts: [2]. In Figure 6 is presented the consumption of electricity per square meter. Electricity consumption per square meter is quite small. Figure 6 shows that the minimum electricity consumption is spent, but it does not mean that influenced the pupils comfort. The school also has a significant generator power from $\mathrm{P}=60[\mathrm{~kW}]$. On the basis of what was stated above, it was difficult to find yearly production of electricity from the generator. Building thermal energy supplied by the heat Termokos.

\subsubsection{The use of efficient lighting}

It is important to note that the main factor affecting power consumption is the number of operating hours per day, on which can be found yearly operation. Another important factor is the power of the lamps to be taken into account for their replacement. Most school space illuminated by fluorescent lamps (about $94 \%$ ). The rest is covered by incandescent lamps and mainly found in the toilets. To make an accurate analysis about the convenience to change the bulbs, should know the average price of electricity is billed schools by KEK. The average price of electricity for the past three years in which the school has been billed 11 [cent/kWh]. It is recommended that incandescent bulbs (the lamps total) be replaced with compact fluorescent lamps 0.018 [W]. In the table 5 presents the benefits that resulting replacement of incandescent lamps with compact fluorescent lamps. Table 5: Comparison of classic lamps with fluorescent lamps: 


\begin{tabular}{|c|c|c|c|c|c|c|c|c|}
\hline Lamp & Number & $\begin{array}{c}\text { Nominal } \\
\text { power } \\
{[\mathrm{kw}]}\end{array}$ & $\begin{array}{c}\text { The total } \\
\text { capacity } \\
\text { installed } \\
{[\mathrm{kw}]}\end{array}$ & $\begin{array}{c}\text { Yearly } \\
\text { hours of } \\
\text { operation }\end{array}$ & $\begin{array}{c}\text { Yearly } \\
\text { energy } \\
\text { consumption } \\
{[\mathrm{kw}]}\end{array}$ & \multicolumn{2}{|c|}{$\begin{array}{c}\text { Price for } \\
\text { [kW/cent] }\end{array}$} & $\begin{array}{l}\text { Price } \\
\text { in } \\
\text { Euros }\end{array}$ \\
\hline Incandescent & 56 & 0.1 & 5.60 & 1000 & 5600 & \multicolumn{2}{|c|}{0.11} & 616 \\
\hline $\begin{array}{l}\text { Compact } \\
\text { fluorescent }\end{array}$ & 56 & 0.018 & 1.01 & 1000 & 4008 & \multicolumn{2}{|c|}{0.11} & 110.88 \\
\hline & & & & \multicolumn{4}{|c|}{ The annual Benefit change of lamps } & 505.12 \\
\hline \multirow[t]{2}{*}{$\begin{array}{l}\text { Fluorescent } \\
\text { lamps }\end{array}$} & Number & $\begin{array}{c}\text { Nominal } \\
\text { power } \\
\text { [kw] }\end{array}$ & \multicolumn{2}{|c|}{$\begin{array}{c}\text { The price of a lamp in } \\
\text { pieces }\end{array}$} & \multicolumn{2}{|c|}{$\begin{array}{l}\text { Total } \\
\text { investment } \\
\text { costs }\end{array}$} & \multicolumn{2}{|c|}{$\begin{array}{c}\text { Hours of } \\
\text { operation } \\
\text { according to } \\
\text { manufacturers }\end{array}$} \\
\hline & 56 & 0.018 & \multicolumn{2}{|c|}{3.50} & \multicolumn{2}{|l|}{196.00} & \multicolumn{2}{|c|}{8000} \\
\hline
\end{tabular}

Annual expenditure by incandescent lighting (by table 5) is 5600 [kWh]. If these 100 [W] incandescent lamps, with longevity 1000 [h], and replaced with 18 [W] compact fluorescent lamps, lifespan 8000 [h], which give the same intensity lighting such as incandescent, yearly expenditure will be 1,008 [kWh], which will be saved 4592 [kWh], per year, about 500 euro respectively: [4], [5].

The total investment cost for the replacement of lamps is 196 euro. Lamp operation time is 8000 hours according to the manufacturer and if compared to the operation of lamps in the school that is about 1000 hours, it appears that these lamps will operate about.

According to Figure 5 and 6 annual benefits will be 505 euro.

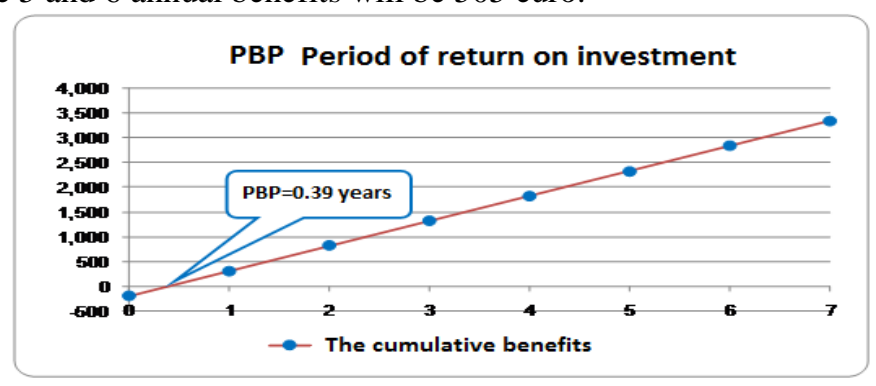

Fig. 7 The period of return on investments

\section{Heating System}

This school building has heating system installed by the city through heat exchangers tiles, water-water. The heating season in this object starts October 15 and ends April 15, and according to the respondents, the heating is not satisfactory. Heating substation in this object is equipped with a temperature regulator, which makes this advanced system in terms of energy efficiency, in terms of heat.

Characteristics of the heating system in this school are:

- Maximum capacity installed changers is not possible to secure, but is dedicated to heating the school and new object - Annex,

- The maximum temperature is $90{ }^{0} \mathrm{C}$

- Maximum pressure is not known, because it lacked the tap insurer,

- Pieces were circulating pumps: two pumps with a capacity of $2[\mathrm{~kW}]$ for two heating zones and a pump installed Willo three stage type with a maximum capacity of 880 [W] and a new facility dedicated to the annex.

Under heating station from the city in this school is not in good condition. Impurity, pipes, valves insulated, significant water losses, not functioning for external temperature sensor, expansion vessel is out of function, not having tap insurers are some of the reasons that the substation should be regulated, 
not only in terms of efficiency, but also because of the long service of these devices. Given that the substation was installing an advanced degree, it necessitates his training-regulation. Troops radiator heater installed in this school are in column form 431.5 capacities [kW] with two, three and four lines. It is noteworthy that these radiators seem to be in good condition.

Also radiators were equipped with mechanical valve at the entrance (not thermostatic) and not well balanced. Distribution piping system that is both tubular steel materials, which appears to be damaged, because the system loses a significant amount of water that enters the system amounts to at least every week. Dedicated distribution pipes for heating facility annex is also two tubular steel, but with distribution near the ceiling and insulated. This can reduce the ability of heat that this object because a large part of the heat will be lost through the middle pipe. Radiators are different number of columns 3 and 4 and 6 to 42 ribs. Power of radiators is given in the following table:

Table 7: Power of radiators:

\begin{tabular}{|c|c|c|c|c|c|}
\hline $\begin{array}{l}\text { Radiators } \\
\text { with columns }\end{array}$ & \multicolumn{5}{|c|}{ Heating capacity radiators for $\mathbf{H}=\mathbf{6 0 0}$} \\
\hline & $\begin{array}{l}\text { Number of } \\
\text { radiators }\end{array}$ & $\begin{array}{l}\text { ribs for } \\
\text { radiator }\end{array}$ & $\begin{array}{l}\text { Capacity for } \\
\text { ribs }[W]\end{array}$ & $\begin{array}{l}\text { The total } \\
\text { number of } \\
\text { columns }\end{array}$ & $\begin{array}{l}\text { The capacity } \\
\text { of all }[\mathrm{kW}]\end{array}$ \\
\hline 2 columns & 10 & 28 & 79 & 280 & 22.12 \\
3 columns & 18 & 16 & 106 & 288 & 30.528 \\
4 columns & 82 & 33 & 140 & 2706 & 378.84 \\
\hline
\end{tabular}

\subsection{Measures to improve efficiency under heat from the city station}

In order to increase efficiency and long service system is required to make some interventions as follows:

- To make the installation of a new valve 3 bar insurers,

- Replace: Thermometer, manometer, thermostat, which measured the outside temperature,

- Expanding the capability of the existing container and recalculated for the case when heat is added to the annex needs new, as are built (2010),

- To increase the level of cleanliness and maintenance,

- Be installed or repaired, if possible new system of water distribution pipes to heat the old facility, which is distributed under the floor,

- Thermostatic valves placed on each radiator (a total of 128 of them),

- Thermally isolate all the pipes, as they hubs, as well as those in the substation, also to isolate all valves except in substation circulating pumps,

- To isolate the pipeline hub in hall annex dedicated to the subject,

- A thermostat placed in the pipe at the pipe entrance changers to three pumps with the help of an electrical contractor. This will contribute to the saving of electricity used when no hot water from the city respectively when the outside temperature is high,

- Filter cleaned every time, when the pressure difference column shows the shipping and return increased to a significant extent compared with the usual decline.

\section{Measures identified for energy saving}

Identified measures for energy conservation, to increase service time, not only heating system, but also its school building are:

- New roof height should be maintained as far as can be and intervention, and shelter (item to be always outside exterior walls). This would increase the need for ventilation at the same time during the summer to protect the object with many of the radiation directly benefit until winter is the same situation. Reconstruction of a new roof and well insulated hydro close by 
infiltration is necessary. It is worth mentioning that the roof leaks at this facility is a real problem that requires an immediate solution, since the roof with a small slope and peaked within the perimeter of the mantle (the ceiling) is quite inappropriate for maintenance;

- Elimination of thermal bridges around windows, ceiling and elsewhere in wrapping are not limited to this subject. In this case should the whole ceiling thermally insulated with glass wool penthouse 10 centimeters, external wall with Styrofoam 8 centimeters and revetments of a door in the hallway in the form of ports, which has considerable infiltration;

- Thermal insulation of the object envelope to school;

- Replacement of windows;

- Solar panels for hot water for the Hall of Physical Education.

\section{Conclusions and Recommendations}

During the inspection, analysis and data collection through school facility Kay and extracting the necessary measures for this facility, as a result of the data needed for a detailed energy audit in this school, as the summary points can be given some conclusions and recommendations:

- The object of this school is in good condition for the functioning of energy efficiency, but that should be some small measure, to be in full and complete saving of energy efficiency;

- During the inspection the object in terms of power, we conclude that the school building meets the technical standards required, as in the electrical installation, as well as lighting. During the inspection the object are verified type of lighting lamps, their number, power installation and operation time;

- Regarding the heating system, according to administrative officials of the school, the heating system is not satisfactory because of the frequent outages Termokos network and as a result of this, we should find other alternatives for heating classes of learners, offices the staff of teachers and administrative staff;

- Improve measures found in the school building to increase energy efficiency. So the school facility needs some investment to raise the level of thermal insulation envelope, as in: exterior walls, roof and in one of the openings of the facade of the school building;

- The average annual consumption of thermal energy per square meter for 2007 is $166\left[\mathrm{kWh} / \mathrm{m}^{2}\right]$ for the year 2008 është $151\left[\mathrm{kWh} / \mathrm{m}^{2}\right]$ and for the year 2009 is $194\left[\mathrm{kWh} / \mathrm{m}^{2}\right]$.

- According to Figure 7 and Table 6, the payback period will be for years, and for years it's time operation lamps, always based on the analysis in Table 6 shows that over the years the school will take about 3339 euros, which worth the investment. So based on this analysis, we conclude that the investment in the replacement of lamps is enough profit for the school;

- With the implementation of these measures identified above, in a short time, we will have increased energy efficiency and energy saving high electrical and thermal.

\section{References}

1. Qelaj, M.: Trajnim profesional për auditor të energjisë, Raport standard auditimi në Sh. F. Dardania: Trajnim për auditor të energjisë, Grupi C: Ministria e Energjisë dhe Minierave. MEM\&Danish Energy Management\&Kantor, Prishtinë (2010)

2. Korporata Energjetike e Kosovës - KEK.: Faturat e energjisë elektrike pr vitet 2007, 2008 dhe 2009, (2010)

3. Rregullore Teknike 03/2009.: Për energji termike dhe mbrojte termike në ndërtesa, MMPH - (2009)

4. Stathis, V., Islami B.: Auditimet e Energjisë në Ndërtesa, Danish Energy Management\&Kantor, Prishtinë (2010)

5. Islami, B., Stathis V: Metodologjia e auditimit të energjisë në Ndërtesa Publike, Trajnim profesional për auditim të energjisë - MEM-Danish Energy Management\&Kantor, Prishtinë (2010) 
6. Theofylaktos C, Transferimi (Transmetimi) i nxehtësisë në ndërtesa. Trajnim për auditor të energjisë - Danish Energy Management\&Kantor, Prishtinë (2010)

7. Danish Energy Management\&Kantor.: Prishtinë 2010, Të dhënat meteorologjike të nevojshme për llogaritje të energjisë për Kosovë - Projekt i trajnimit të auditorëve të energjisë, Europe Aid /127849/C/SER/KOS 2010

8. Stathis, V.: Politika e energjisë në BE, Europe Aid/127849/C/SER/KOS: Zyra Ndërlidhëse e Komisionit Evropian në Kosovë, (2010)

9. Shiroka-Pula, J., Qelaj, M. dhe Xhelili-Krasniqi, F. „European and International Standards and their role in Small and Medium Enterprises", No 3, ISSN 2232-8742 'EFECTS OF GLOBAL RISK IN TRANSITION COUNTRIES', University ' Haxhi Zeka', State University of Zenica-Fakulty of Law dhe European University College Dukagjini, Peja Republic of Kosovo, (2013) http://www.dukagjinicollege.eu/libri3/standards....pdf 